\title{
A koragyermekkori intervenció rendszere - utak és kapcsolódások
}

\author{
Kereki Judit \\ Állami Egészségügyi Ellátó Központ, ELTE Bárczi Gusztáv Gyógypedagógiai Kar Általános \\ Gyógypedagógiai Intézet és Atipikus Viselkedés és Kogníció Gyógypedagógiai Intézet
}

\begin{abstract}
A koragyermekkori intervenció hazai helyzetre adaptálható értelmezése, célcsoportjának meghatározása mellett a tanulmány kitér a tevékenység fontosságának legfontosabb érveire. Rövid nemzetközi kitekintéssel alapozza meg a hazai ellátórendszer müködésének bemutatását, fókuszába állitva a különböző, koragyermekkori intervencióban érintett területek (egészségügy, oktatás-köznevelés, szociális/gyermekvédelem) intézményes szereplöinek illetve azok tevékenységeinek, valamint a közöttük lévő kapcsolódásoknak az ismertetését a jelenlegi szabályozás tükrében. A gyermek útja több szakaszra tagolható, a prekoncepcionális szakasztól a várandósság és a perinatális időszakon keresztül a hazakerülés utáni szakaszig, egészen a gyermek iskolába lépéséig. Minden szakaszban megtalálhatóak azok a kulcsintézmények, illetve szereplők, amelyek/akik az ellátásban részt vesznek, feladataik jogszabály által meghatározottak, és közöttük a továbbküldési, jelzési utak is leírhatóak. A hiányzó kapcsolódások azonositása segít abban, hogy a különbözö ágazati irányítás alá tartozó intézményeket összekötő, rendszerszinten megvalósuló szabályozott kliensút kialakitására kerülhessen sor.
\end{abstract}

Kulcsszavak: koragyermekkori intervenció, intézményrendszer, szabályozás, hatékonyság, gyermek-és kliensút

\section{Bevezetés}

Az utóbbi néhány évben a különböző ágazatok égisze alatt lezajló kutatások, fejlesztési projektek eredményei, a hazai szakemberek elszánt kezdeményezései és az uniós fejlesztési trendek hazánkban is ráirányították a figyelmet a koragyermekkori intervenció fontosságára. Kedvező fejlemény, hogy a kormányzati elképzelések között is egyre hangsúlyosabb szerepet kap a korai életszakasz, a koragyermekkori intervenció témaköre. 2014-ben elkezdődött egy folyamat, amelynek része a koragyermekkori intervenció stratégiai elképzeléseinek megfogalmazása, nagy átfogó fejlesztési projektek tervezése, illetve azoknak a szolgáltatásoknak, ellátásoknak a hatékonyabb müködtetésére való törekvés, amelyek az iskoláskor előtti gyerekek és családjaik támogatását hivatottak biztosítani. A koragyermekkori intervenció több ágazat munkamegosztásában zajlik, a köznevelési, az egészségügyi, a szociális és társadalmi felzárkózásért felelös terület, de a család- és ifjúságügy, valamint a közigazgatás is érintett. Eddig nem volt igazán felelőse a területnek, hiányzott az összehangolt döntéshozói együttmüködés, ami nehézkessé tette a rendszer müködését. 2014-töl a Család- és Ifjúságügyi Államtitkárság látja el a koragyermekkori intervenció koordinációjának feladatát.

Ebben a fejlődésre nyitott helyzetben szakmai és közpolitikai szempontból is megkerülhetetlen feladat a koragyermekkori intervenció elméleti kereteinek kialakítása, a különböző intézményrendszerek müködésének ismertetése, kapcsolódásaik áttekintése, a rendszerben azonosítható problématerületek leírása, amelyek segítik azt, hogy jól megalapozott fejlesztési projektek, modellkísérletek segítségével rendszerszintűvé emelhető 
elképzelések valósulhassanak meg. Jelen tanulmányban a koragyermekkori intervenció hazai helyzetre is jól adaptálható értelmezését, prioritássá emelésének legfontosabb érveit ismertetem, rövid nemzetközi kitekintéssel. Majd az intézményrendszer szereplőit, tevékenységeit illetve kapcsolódásait mutatom be a gyermekút állomásain keresztül a jelenlegi szabályozás tükrében, keretezve a legfontosabb problématerületek és az azokra adott megoldási kísérletek összegzésével.

\section{Mi a koragyermekkori intervenció?}

A nemzetközi szakirodalomban a koragyermekkori intervenció definícióját tekintve eltérő értelmezések találhatóak, amelyek mind az ellátási időszak lehatárolásában, mind a célcsoport korosztály szerinti, problématerület szerinti meghatározásában különbséget mutatnak. A European Agency for Special Needs and Inclusive Education nemzetközi szervezet 26 európai ország gyakorlata alapján leírt, konszenzuson alapuló meghatározását (Id. EADSINE 2010) és a hazai terepen szerzett eddigi tapasztalatokat, definíciókat figyelembe véve (ICSSZEM, 2005; Kereki, 2011; Kereki és mtsai, 2014; Kereki és Szvatkó, 2015) összegezhető a jelenlegi értelmezés.

A szélesebb értelemben vett koragyermekkori intervenció magában foglalja a prekoncepcionális időszak preventív jellegű szolgáltatásait, valamint a fogantatástól a gyermek iskolába lépéséig a gyermekekre és családjaikra irányuló ellátások szolgáltatások összességét. Beletartozik minden olyan tevékenység, amely a gyermekek és családjaik speciális támogatását szolgálja a gyermek személyes fejlődése, a család saját kompetenciájának megerősítése, valamint a gyermek és a család szociális befogadása érdekében. A koragyermekkori intervenció a szürés szakaszától, a probléma felismerésétől és jelzésétől kezdve a diagnosztizáláson keresztül magában foglalja a különböző habilitációs/rehabilitációs, a (pszicho)terápiás, valamint a gyógypedagógiai tanácsadó és fejlesztő tevékenységet, illetve a juttatások rendszerét is. Szemléletében kiemelten fontos a prevenciós elem, beleértve a mentális egészséget, a viselkedésszabályozást veszélyeztető kapcsolati mintázatok kedvező befolyásolását.

A koragyermekkori intervenció felöleli a minden gyermekre és családjukra kiterjedő prevenciós szemléletü, a gyermek korai életszakaszában nyújtott ellátásokat, szolgáltatásokat. Ezen belül a szolgáltatások célzottan több speciális támogatást igénylő csoportra fókuszálnak, így ide sorolhatóak (1) a fejlődési rizikóval született, a sérült, eltérő vagy megkésett fejlődésü, fogyatékos, krónikus beteg; (2) a pszichés fejlődés szempontjából veszélyeztetett; (3) a szociálisan hátrányos helyzetű, valamint (4) a kiemelten tehetséges gyermekek és családjaik, akik a korai beavatkozások sokszor egymást átfedő célcsoportjait képezik ${ }^{1}$. A teljeskörüség gondolatában tehát ott van a differenciált megközelítés is, amely ezeknek a gyerekcsoportoknak illetve családjaiknak a különböző szükségletei felöl ragadja meg a prevenciós illetve intervenciós tevékenységek tartalmát (Kereki, 2011).

\footnotetext{
1 A célcsoport kialakításánál szempontként merült fel a köznevelési törvény kiemelt figyelmet igénylő gyermekekre vonatkozó felosztása. Eszerint a kiemelt figyelmet igénylő gyermekek körébe tartoznak a hátrányos helyzetü, halmozottan hátrányos helyzetű, valamint a különleges bánásmódot igénylő gyermekek. Az utóbbi kör három csoportra bontható: a sajátos nevelési igényű gyerekek, a beilleszkedési, tanulási, magatartási nehézséggel küzdők valamint a kiemelten tehetséges gyerekek csoportjára. (2011. évi CXC. törvény a nemzeti köznevelésröl, 4.§. 13.) A kiemelten tehetséges gyerekek esetében a beavatkozás nem csak a tehetségük kibontakoztatását szolgálja, hanem a gyermekkor védettségének megtartását is.
} 


\section{A koragyermekkori intervenció fontossága}

Az utóbbi évtizedekben a neurobiológia, a viselkedéstudományok és társadalomtudományok területén zajló kutatások nagy elörelépéshez vezettek azoknak a tényezőknek az azonosításában, amelyek a gyerekek életkezdetét kedvező vagy kedvezőtlen módon befolyásolják. A fejlődés a korai életszakaszban a leggyorsabb, a megszerzett élmények, tapasztalatok az agyi struktúrákba integrálódva megalapozzák a mozgásos, kognitív, nyelvi funkciók kiépülését, a szociális, önszabályozó képesség valamint az érzelmi biztonság kialakulását (Shonkoff és Phillips, 2000). Ugyanakkor a gyerekek sérülékenységének kockázata is ekkor a legnagyobb, az egészséges fejlődést számos tényező veszélyezteti, a biológiai károsodások, a kedvezötlen szocioökonomiai jellemzők, környezeti feltételek és az érzelmi, pszichés sérülések egyaránt befolyásolhatják azt.

A gyermek fejlődésére ható káros tényezők megelőzésének fontosságán vagy a minél korábbi beavatkozások egyéni fejlődést befolyásoló meghatározó jelentőségén túl nem tekinthetünk el a korai életszakaszban nyújtott prevenciós és intervenciós támogatások hosszú távú társadalmi hasznosságától sem, hiszen ezek - a kutatási eredmények szerint - költséghatékonyabbak, eredményesebbek, mint a később nyújtott beavatkozások. Azok a költséghaszon elemzések, amelyek a korai évekbe való befektetések megtérülését vizsgálták, úgy találták, hogy minél korábbi életkorban történnek a beavatkozások, annál magasabbak a beruházások hosszú távú megtérülési rátái. Először Carnerio és Heckman (2003) írták le, hogy az iskoláskor elötti beruházások megtérülési rátái magasabbak, mint az iskoláskor utáni ráták (Carnerio és Heckman, 2003). Később ez a megállapítás differenciálódott, Heckman részletesebb életkor szerinti bontásban írta le az emberi tőke beruházás megtérülési rátájának változását (Heckman, 2008a, 2008b) (lásd 1. ábra). Mindez a várandóság szakaszára kivetíthető, hipotetikusan megközelítve, ha a befektetés már a születés előtt kezdődik, akkor annak megtérülési rátája magasabb, mint a születés után megkezdett beavatkozásoké (lásd 2. ábra) (Doyle, Harmon, Heckman és Tremblayd, 2009).

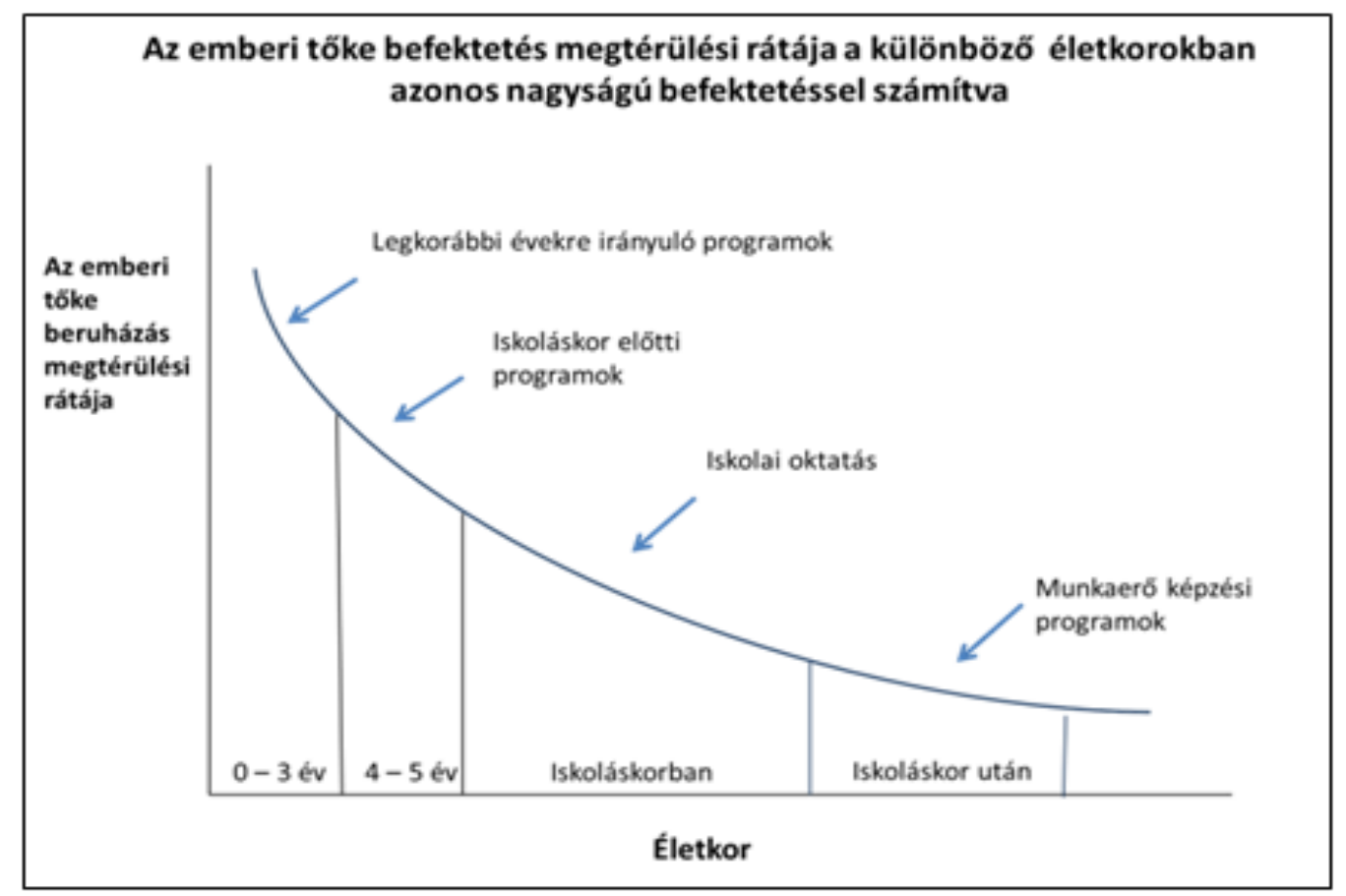

1. ábra: Az emberitőke-befektetés megtérülési rátája a különböző életkorokban, azonos nagyságú befektetéssel számítva (forrás: Heckman, 2008a, 2008b) 


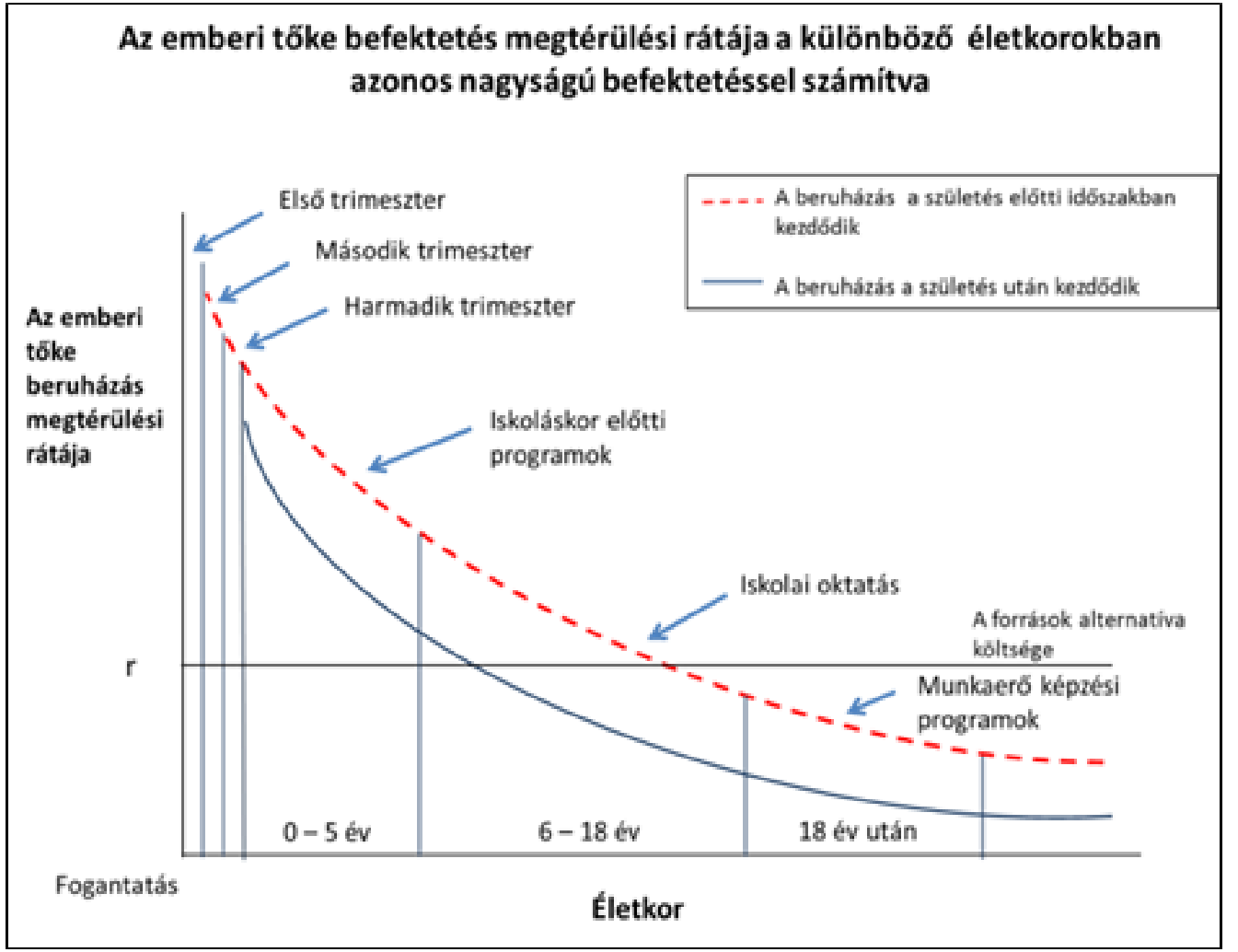

2. ábra: Az emberitőke-befektetés megtérülési rátája a különböző életkorokban, azonos nagyságú befektetéssel számítva (forrás: Doyle et al, 2009)

A korai életszakasz prioritása érvényre kell, hogy jusson a gyerekjogokat megfogalmazó hivatalos dokumentumokban, jogszabályokban is. 1959-ben az ENSZ Emberi Jogi Bizottság által előkészített a Gyermek Jogairól Szóló Nyilatkozata határozottan állást foglal a gyermek egészséges fejlődéséhez való jogáról és különleges szükségletei esetén a megfelelő szolgáltatás biztosításának szükségességéről. „A gyermek élvezi a társadalombiztosítás juttatásait. Joga van az egészséges növekedésre és fejlődésre; ebböl a célból különleges gondoskodást és védelmet kell biztosítani mind a gyermek, mind az anya számára, beleértve a megfelelő születés elötti és születés utáni gondoskodást. A gyermeknek joga van a megfelelö táplálkozásra, lakásra, szórakozásra és orvosi szolgáltatásokra." (ENSZ Nyilatkozat a gyermekek jogairól, 1958, 4. alapelv)

Az 1989-es ENSZ Gyermekjogi Egyezmény azokat az alapvető jogokat foglalja össze, amelyeket az egyezményt aláíró államoknak a gyermekek jólléte érdekében biztosítania kell. „Az Egyezményben részes államok elismerik a gyermeknek a lehető legjobb egészségi állapothoz való jogát, valamint, hogy orvosi ellátásban és gyógyítónevelésben részesülhessen. Erőfeszítéseket tesznek annak biztosítására, hogy egyetlen gyermek se legyen megfosztva az ezeknek a szolgáltatásoknak az igénybevételére irányuló jogától."2 Magyarország 1991-ben ratifikálta a Gyermekjogi Egyezményt³.

Az 1993. december 20-i ENSZ közgyülésen fogadták el a Fogyatékossággal élő emberek esélyegyenlőségének szabályai c. dokumentumot, amely a korai felismerés

\footnotetext{
${ }^{2}$ A Gyermek jogairól szóló ENSZ Egyezmény, 1989, 24. cikkely, 1. bek.) http://www.szmm.gov.hu/download. php?ctag=download\&docID=14922 (Letöltés dátuma: 2015. 03.05.)

3 Hazánkban az ENSZ egyezmény az 1991. évi LXIV. törvénnyel került kihirdetésre: 1991. évi LXIV. törvény a Gyermek jogairól szóló, New Yorkban, 1989. november 20-án kelt Egyezmény kihirdetéséről.
} 
A koragyermekkori intervenció rendszere - utak és kapcsolódások

fontosságára hívja fel a figyelmet: „Az Egyezményben részes államok a sérülés korai felismerését, illetve mérését, kezelését célzó programokat biztositanak, amelyeket különböző tudományterületekröl érkező szakemberek csoportja végez. Ezzel megelőzhetök, csökkenthetők, vagy megszüntethetők a fogyatékosságot okozó tényezők." Magyarországon ennek a dokumentumnak a felhasználásával készült az 1998. évi XXVI. törvény a fogyatékos személyek jogairól és esélyegyenlőségük biztosításáról, amelynek a korai ellátásra vonatkozó kitétele szerint: „A fogyatékos személynek joga, hogy állapotának megfelelően és életkorától függően korai fejlesztésben és gondozásban, óvodai nevelésben...vegyen részt a vonatkozó jogszabályokban meghatározottak szerint."

Ugyancsak európai uniós dokumentumok hazai jogrendszerbe való illesztésével született meg az egyenlő bánásmódról és az esélyegyenlőség előmozdításáról szóló 2003. évi XXV. törvény, amely a prevenció és a szürés, felismerés fontosságára, illetve ennek mindenki számára való biztosítására hívja fel a figyelmet: „Az egyenlő bánásmód követelményét a szociális biztonsággal összefüggésben érvényesíteni kell, különösen az egészségügyi szolgáltatásnyújtás, ezen belül (a) a betegségmegelőző programokban és a szürővizsgálatokon való részvétel, (b) a gyógyító - megelőző ellátás...során"6.

Miközben az 1997. évi gyermekvédelmi törvényben a gyermeki jogok között ott találjuk a szülő kötelezettségét, hogy gyermeke testi, értelmi, érzelmi és erkölcsi fejlődéséhez szükséges feltételeket biztosítsa, illetve a gyermek jogát az egészséges fejlődéshez, valamint a fogyatékos gyermek jogát a fejlődését és személyisége kibontakozását segítő különleges ellátáshoz ${ }^{7}$, a szülő nem kötelezhető arra, hogy a köznevelési törvényben biztosított korai fejlesztést igénybe vegye. Ugyancsak rajta múlik, hogy a nem kötelező szúrésekre, az orvosi vizsgálatokra vagy 3 éves kor alatt a szakértői bizottsági vizsgálatokra elviszi-e a gyermekét.

\section{Rövid nemzetközi kitekintés a koragyermekkori intervenció gyakorlatáról}

Az európai országokban a koragyermekkori intervenciós intézményrendszer szerveződése nagyon eltérő formákat ölt. Vannak országok, ahol csak néhány évre tekint vissza a rendszer kialakítása, lassan alakul ki a szervezeti háttér, mint Görögország, Észtország vagy Csehország esetében, és vannak olyanok is, mint például a német nyelvű országok, ahol több évtizedes tapasztalattal rendelkeznek a rendszer müködtetéséről.

A német nyelvterületek közös jellemzője, hogy a koragyermekkori intervenció több évtizedes múlttal rendelkező, kiterjedt, és jól működő intézményrendszerre támaszkodik. Az ellátás kulcsfogalmai: a rendszerszemlélet, a szülői részvétel és beleszólási jog. Németországban az ellátás hálózatos formában valósul meg, az egészségügyi (tanácsadás, gyermekellátás), a korai fejlesztő, a gyermekvédelmi és a szociális ellátások intézményei közötti szoros kooperáció segítségével. Amennyiben a család- vagy gyerekorvosok valamilyen fejlődési rendellenesség gyanúját észlelik, továbbküldik a családot a korai fejlesztő központokba vagy a szociálpediátriai intézetekbe, amelyek kiterjedt intézményhálózatba szerveződve látják el a gyerekeket, családokat. Egyetlen családnak sem kell 10 kilométernél messzebbre utaznia a legközelebbi ellátó központig. A korai fejlesztő központokban elsősorban mobil és ambuláns ellátás folyik. A mobil ellátás a gyermek otthonában vagy más

\footnotetext{
4 United Nations Organization (1993):The Standard Rules on the Equalization of Opportunities for Persons with Disabilities. New York: UN, 2. szabály, 1. §. http://www.un.org/disabilities/default.asp?id=26 (Letöltés dátuma: 2015. 03.05.)

5 1998. évi XXVI. törvény a fogyatékos személyek jogairól és esélyegyenlőségük biztosításáról, 13. §., 1.

6 2003. évi XXV. törvény az egyenlő bánásmódról és az esélyegyenlőség előmozdításáról, 25 . §., 1.

7 1997. évi XXXI. Törvény a gyermekek védelméröl és a gyámügyi igazgatásról, 12. §, illetve 6. § (1), (2), (3)
} 
természetes közegében (pl. bölcsőde, óvoda) valósul meg. A szociálpediátriai központok speciális ambulanciák, ahol diagnosztikus, terápiás ellátást biztosítanak, és koordinálják a különböző ellátásokat (0-18 éves korig) (EADSNE, 2005, 2010; Peterander, 2004, 2009).

A skandináv országok esetében nincs szervezett intézményrendszer, alapvetöen az önkormányzatok feladata a koragyermekkori intervenció megszervezése. Az országcsoport közös jellemzője, hogy lényegében nincs külön kiépített koragyermekkori intervenciós ellátórendszer, és nincsenek nagy korai fejlesztő központok. Ehelyett integráltan próbálják a koragyermekkori intervencióra szoruló gyermekeket a szociális és oktatási ellátó rendszer főáramában tartani, kortársaik között (Luttropp, Norling és Balton, 2007). A bölcsődei és az óvodai hálózat kiterjedt és jól működik, ami elsősorban annak köszönhető, hogy a gyermekek nagy része már egyéves kora után intézményi ellátásba kerül a szülök korai munkába való visszatérése miatt. A jól kiépített kora- és kisgyermekkori intézményhálózat a koragyermekkori intervenció funkcióinak ellátására is alkalmas. Jellemző a személyre szabott megközelítés, a kliensek személyes felkeresése, nyomon követése (védőnő vagy ifjúsági referens, szociális munkás által.) A gyermekek fejlődését születésüktől egyéves korukig rendszeres orvosi vizsgálatokkal ellenőrzik, probléma esetén a sürün kontrollált periódus két és fél évre is meghosszabbítható (Almqvist, 2009; Helgevold, 2009; Svendsen, 2009; Heinämäki, 2009).

A mediterrán országcsoport közös jellemzője, hogy a koragyermekkori intézményrendszer müködési elveit és a finanszírozás kérdéseit csak jó egy évtizede foglalták jogszabályba. Ennek ellenére (vagy éppen ezért) a mediterrán országok korai ellátása az elmúlt évtizedben látványos fejlődésen ment keresztül, és mára jó példaként hoznak fel több, az ellátórendszer müködtetésével kapcsolatos itt alkalmazott gyakorlatot (Euronews, 2006). Spanyolországban 2000-ben fogadták el (majd 2005ben megújították) a Koragyermekkori Intervenciós Fehér Könyvet, mely az ágazat holisztikus és komplex megközelítését kívánja elősegíteni. A stratégiai anyag egy átfogó bio-pszicho-szociális modellt alapul véve a koragyermekkori intervenciót a gyermek, a család és a közösség szükségletei kielégítése érdekében kifejtett komplex tevékenységnek tekinti (Libro Blanco, 2000, 2005). Az eltérő vagy megkésett fejlődésü, 0-6 éves gyermekek korai fejlesztése, terápiás ellátása föként centrumokban, illetve családközpontú tevékenységek keretében történik, ahol interdiszciplináris team foglalkozik a gyermekkel és családjával. A támogatásokhoz a regionális önkormányzatokhoz tartozó szociális szolgáltató hálózat szervezi meg a hozzáférést. Valamennyi nyújtott szolgáltatás díjmentes (Ponte, 2004; Veerman, 2009; Guitez, 2010).

Az angol rendszer a decentralizált rendszerek közé tartozik. A törekvések között szerepel, hogy a koragyermekkori intervenciós szolgáltatások, ellátások a lehető legközelebb kerüljenek a családokhoz. Az országban nemzeti szürési program müködik, protokollok mentén kapcsolódik össze több különböző szolgáltatással, ennek célja, hogy minél korábban felismerjék a problémát, és minél hamarabb vizsgálatra küldjék azokat a gyerekeket és családokat, ahol a szürés során felmerül a gyanú (Andrews, 2009). Segítik a családok és a velük dolgozó teamek együttmüködését, a szülői partnerségre építenek, rendszeres találkozókat, tréningeket szerveznek, támogatják a szülőt a gyermekét érintő döntések meghozatalában. A család és a szakértői csoport egyéni családszolgáltatási tervet dolgoz ki, amely a család szükségleteit, erősségeit, a célokat, prioritásokat, valamint az elvégzendő és a kiértékelendő feladatokat tartalmazza. Ahol szükséges, ott egy vezető szakember vagy egy "kulcsszemély” támogatja rendszeresen a családot (Early Support, 2012). Az interdiszciplináris csapatmunka különbözőképpen szerveződik. Néhány helyi fejlesztő központban az utazó tanári szolgáltatások (Portage-modell) az egészségügyi szolgáltatásokkal, az orvosi és a terápiás segítséggel együtt müködnek. De ez nem mindenhol van 
A koragyermekkori intervenció rendszere - utak és kapcsolódások

így. Ezért a szakembereket arra ösztönzik, hogy a koragyermekkori intervenciós centrumokban törekedjenek a stabil interdiszciplináris teamek kialakítására (Carpenter és Russel, 2005; EADSNE, 2005; Robertson és Messenger, 2010).

\section{A hazai koragyermekkori intervenciós rendszer}

A hazai koragyermekkori intervenciós intézményrendszer szereplői közé soroljuk mindazokat az egészségügyi, köznevelési, szociális, gyermekvédelmi, gyermekjóléti illetve egyéb intézményeket, valamint mindezek képviselőit, akik a fogantatástól a gyermek iskolába kerüléséig a speciális támogatást igénylő gyermekekkel illetve családjaikkal kapcsolatba kerülnek. Munkájuk a rendszer működésének különböző szakaszaihoz, egyrészt a felismerés, szűrés, jelzés folyamatához, másrészt a diagnosztika szakaszához, harmadrészt az ellátások, juttatások, szolgáltatások rendszeréhez kapcsolódik. A különböző ágazati irányítású illetve egyéb intézmények és szakemberek listáját az összegző táblázat tartalmazza:

\begin{tabular}{|c|c|c|c|}
\hline Köznevelés $^{8}$ & Egészségügy ${ }^{9}$ & $\begin{array}{c}\text { Szociális/ } \\
\text { gyermekvédelem }^{10} \\
\end{array}$ & Egyéb intézmények \\
\hline Óvoda ${ }^{11}$ & $\begin{array}{l}\text { Védőnő } \\
\text { • } \quad \text { családvédelmi } \\
\text { szolgálat védőnője } \\
\text { • } \quad \text { kórházi védőnő } \\
\text { • } \quad \text { területi védőnő }\end{array}$ & $\begin{array}{l}\text { Falu- és tanya- } \\
\text { gondnoki szolgálat }\end{array}$ & $\begin{array}{l}\text { Magánellátók } \\
\text { - } \quad \text { egyéb korai fejlesz- } \\
\text { tést végző intézmé- } \\
\text { nyek, } \\
\text { - } \quad \text { korai diagnosz- } \\
\text { tikát, terápiát, } \\
\text { utánkövetést végző } \\
\text { intézet (eü), } \\
\text { - egyéb egészség- } \\
\text { ügyi finanszírozású } \\
\text { szolgáltatók }\end{array}$ \\
\hline \multirow{6}{*}{$\begin{array}{l}\text { Pedagógiai } \\
\text { szakszolgálati } \\
\text { intézmény } \\
\text { - } \quad \text { tankerületi } \\
\text { pedagógiai } \\
\text { szakszolgálat, } \\
\text { - megyei/fővárosi } \\
\text { pedagógiai } \\
\text { szakszolgálat, } \\
\text { országos } \\
\text { tagintézmény } \\
\text { (országos szakértői } \\
\text { bizottság) }\end{array}$} & \multirow[t]{2}{*}{$\begin{array}{l}\text { Házi gyermekorvos, } \\
\text { háziorvos }\end{array}$} & Családsegítő szolgálat & $\begin{array}{l}\text { Fogyatékos személyek } \\
\text { érdekvédelmi } \\
\text { szervezetei }\end{array}$ \\
\hline & & Támogató szolgálat & Önkormányzatok \\
\hline & Szülészet & Nappali ellátó intézmény & Kormányhivatal \\
\hline & $\begin{array}{l}\text { Perinatális (neonatális) } \\
\text { intenzív centrum }\end{array}$ & $\begin{array}{l}\text { Fogyatékos személyek } \\
\text { otthona }\end{array}$ & Rendőrség \\
\hline & $\begin{array}{l}\text { Újszülöttosztály, } \\
\text { csecsemőosztály }\end{array}$ & Gyermekjóléti szolgálat & Bíróság \\
\hline & $\begin{array}{l}\text { Gyermek habilitációs/ } \\
\text { rehabilitációs } \\
\text { intézmények }\end{array}$ & Biztos Kezdet Gyerekház & Ügyészség \\
\hline
\end{tabular}

8 A résztvevő intézmények és szakemberek feladatait a 2011. évi CXC. törvény a nemzeti köznevelésről és a 15/2013. (II.26.) EMMI rendelet a pedagógiai szakszolgálati intézmények működéséről tartalmazza.

9 60/2003. (X. 20.) ESzCsM rendelet az egészségügyi szolgáltatások nyújtásához szükséges szakmai minimumfeltételekröl.

10 A résztvevő intézmények és szakemberek feladatait az 1993. évi III. törvény a szociális igazgatásról és szociális ellátásokról és az 1/2000. (I. 7.) SzCsM rendelet a személyes gondoskodást nyújtó szociális intézmények szakmai feladatairól és működésük feltételeiről 3. sz. melléklet, valamint az 1997. évi XXXI. törvény a gyermekek védelméről és a gyámügyi igazgatásról és a 15/1998. (IV. 30.) NM rendelet a személyes gondoskodást nyújtó gyermekjóléti, gyermekvédelmi intézmények, valamint személyek szakmai feladatairól és működésük feltételeiről 2 . sz. melléklet, továbbá a 29/2012. (III. 7.) Korm. rendelet a közszolgálati tisztviselők képesítési elöírásairól 2. sz. melléklet tartalmazza.

11 A szélesebb értelemben vett koragyermekkori intervenciós intézményrendszer elemei közé tartozik az óvoda is, hiszen az iskoláskor előtti gyerekek ellátásában (adott esetben speciális szolgáltatások nyújtásával) részt vesz. 


\begin{tabular}{|c|c|c|c|}
\hline \multirow[t]{6}{*}{$\begin{array}{l}\text { Egységes } \\
\text { gyógypedagógiai, } \\
\text { konduktív pedagógiai } \\
\text { módszertani intézmény } \\
\text { (EGYMI) }\end{array}$} & \multirow[t]{6}{*}{ Speciális szakellátás } & $\begin{array}{l}\text { Napközbeni ellátások: } \\
\text { bölcsőde, családi } \\
\text { napközi, családi } \\
\text { gyermekfelügyelet, házi } \\
\text { gyermekfelügyelet, } \\
\text { alternatív napközbeni } \\
\text { ellátások }\end{array}$ & $\begin{array}{l}\text { Klebelsberg Kunó } \\
\text { Intézményfenntartó } \\
\text { Központ }\end{array}$ \\
\hline & & $\begin{array}{l}\text { Gyermekek } \\
\text { átmeneti otthon }\end{array}$ & \multirow{6}{*}{$\begin{array}{l}\text { Szociális és } \\
\text { Gyermekvédelmi } \\
\text { Főigazgatóság }\end{array}$} \\
\hline & & $\begin{array}{l}\text { Családok átmeneti } \\
\text { otthona }\end{array}$ & \\
\hline & & Gyermekotthon & \\
\hline & & $\begin{array}{l}\text { Területi gyermekvédelmi } \\
\text { szolgálat }\end{array}$ & \\
\hline & & Gyámhatóság & \\
\hline $\begin{array}{ll}\text { Szakemberek: } \\
& \text { óvodapedagógus } \\
& \text { lyozottlak pedagó- } \\
\text { giája szakirányon } \\
\text { végzett gyógypeda- } \\
\text { gógus, } \\
\text { tanulásban akadá- } \\
\text { lyozottak pedagó- } \\
\text { giája szakirányon } \\
\text { végzett gyógypeda- } \\
\text { gógus } \\
\text { - logopédus, } \\
\text { látássérültek peda- } \\
\text { gógiája szakirányon } \\
\text { végzett gyógypeda- } \\
\text { gógus, } \\
\text { hallássérültek } \\
\text { pedagógiája szak- } \\
\text { irányon végzett } \\
\text { gyógypedagógus, } \\
\text { pszichopedagógus, } \\
\text { szomatopedagógus } \\
\text { autizmus spektrum } \\
\text { pedagógiája szak- } \\
\text { irányon végzett } \\
\text { gyógypedagógus } \\
\text { gyógytornász, } \\
\text { konduktor } \\
\text { (klinikai szak)pszi- } \\
\text { chológus } \\
\text { gyermekpszichiáter }\end{array}$ & $\begin{array}{l}\text { Szakemberek: } \\
\text { - } \text { szülész- } \\
\text { nögyógyász, } \\
\text { neonatológus, } \\
\text { - gyermek-neuro- } \\
\text { lógus, gyermek- } \\
\text { pszichiáter, } \\
\text { klinikai szakpszi- } \\
\text { chológus } \\
\text { - genetikus, } \\
\text { - } \quad \text { szemész, } \\
\text { - fül-orr-gégész, } \\
\text { - } \quad \text { oudiológus, } \\
\text { ortopéd szak- } \\
\text { orvos, } \\
\text { - gyermek-rehabili- } \\
\text { tációs szakorvos, } \\
\text { - fogorvos } \\
\text { - dietetikus } \\
\text { egyéb szakorvos }\end{array}$ & 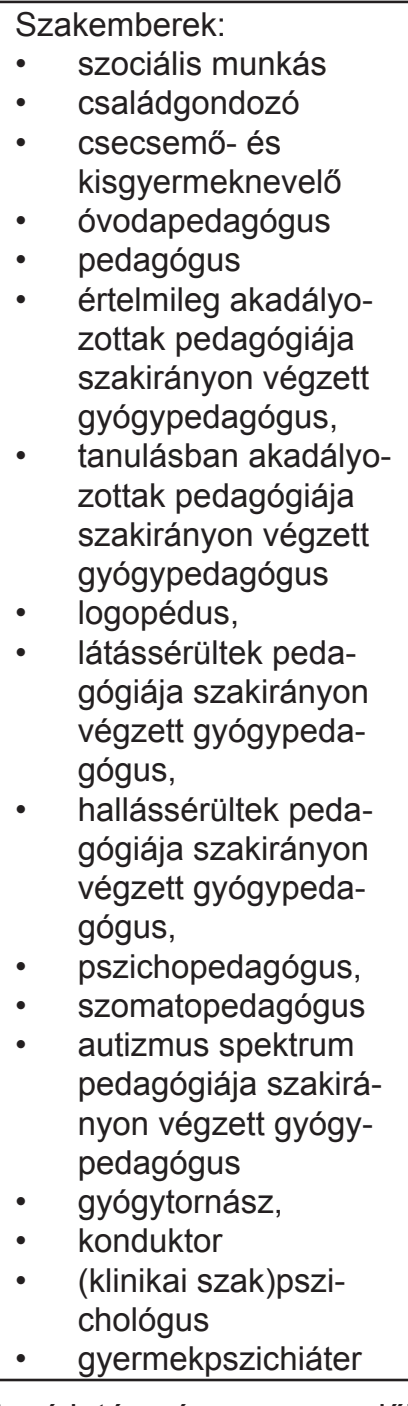 & \\
\hline
\end{tabular}

1. táblázat: Különböző ágazati irányítás alá tartozó intézményes szereplök (forrás: Kereki, 2014)

\subsection{Egészségügyi ellátórendszer}

A legismertebb ellátórendszer az egészségügyi ellátások rendszere, amelynek keretében müködik az alapellátás, a járóbeteg-szakellátás, a fekvőbeteg-szakellátás, valamint egyéb egészségügyi ellátási formák. Az alapellátást az ellátott személy lakóhelyén, illetve annak közelében kell biztosítani, hogy választása alapján igénybe vehető, 
személyes kapcsolaton alapuló folyamatos egészségügyi ellátásban részesülhessen ${ }^{12}$. Az egészségügyi alapellátás témánkat érintő legfontosabb intézményei: a háziorvosi, házi gyermekorvosi, valamint a védőnői ellátás. Az általános járóbeteg-szakellátás keretében a szakorvos által végzett egyszeri, illetve alkalomszerü egészségügyi ellátás zajlik, amely a beteg folyamatos ellátását, gondozását végző orvos beutalása vagy az egyén jelentkezése alapján történik (pl. szemészet, fül-orr gégészet, audiológia, ortopédia, gyermekneurológia, gyermekpszichiátria keretén belül). A fekvőbeteg-ellátást nem igénylő krónikus betegség esetén történő folyamatos szakorvosi gondozás is ide tartozik ${ }^{13}$.

A fekvőbeteg-szakellátás az ellátott lakóhelye közelében levő fekvőbeteggyógyintézeti keretek között végzett egészségügyi ellátás. Igénybevétele az ellátást végző orvos, a kezelőorvos beutalása, valamint a beteg jelentkezése alapján történik. $A$ fekvőbeteg-ellátás jellemzően folyamatos benntartózkodás mellett végzett diagnosztikai, gyógykezelési, rehabilitációs vagy ápolási célú fekvőbeteg-gyógyintézeti ellátás ${ }^{14}$. (Ilyen ellátás zajlik pl. a perinatális (neonatális) intenzív centrumban, az újszülött- vagy csecsemőosztályon, a gyermek habilitációs/rehabilitációs osztályokon, intézményekben.) Az általános ellátás mellett az egyes speciális diagnosztikai és terápiás háttér, illetve a speciális fekvőbeteg-szakellátás biztosítása is szükséges (pl. krónikus beteg gyermekek esetében) ${ }^{15}$. A törvényben meghatározott egyéb egészségügyi ellátások körébe tartozik többek között az ügyeleti ellátás, a mentés, a betegszállítás, az ápolás, egyes különleges ellátási igényt kielégítő egészségügyi szolgáltatások, a rehabilitáció, az orvostechnikai eszközellátás, a gyógyszerellátás, a pszichoterápia és klinikai szakpszichológia, a nem-konvencionális gyógyító és életminőség-javító eljárások, egyéb gyógyászati ellátások ${ }^{16}$.

Fontos kitétele az egészségügyi törvénynek a prevenció hangsúlyozása, és ebben a társágazatokkal való együttműködés szükségessége. „Az egészségügyi alapellátás és szakellátás területén működő egészségügyi szolgáltatók feladataik ellátása során kiemelt figyelmet fordítanak a gyermekek egészségét veszélyeztető tényezők megelőzésére, felismerésére és megszüntetésére. Ennek érdekében együttmüködnek a közoktatási, a szociális és családsegítő, valamint a gyermekek védelmét ellátó intézményekkel, személyekkel, és szükség esetén megfelelő intézkedést kezdeményeznek."17

\subsection{Köznevelés rendszere}

Az utóbbi években az intézményrendszer a centralizációs törekvések következtében nagy átalakuláson ment keresztül, amely a köznevelést és a szociális, gyermekvédelmi területet egyaránt érintette. A köznevelés területén 2013 januárjától az egyházi, magán- és alapítványi intézmények kivételével az összes általános iskola, középiskola, szakiskola, kollégium, és pedagógiai szakszolgálat az önkormányzatoktól a Klebelsberg Kunó Intézményfenntartó Központ fenntartása és szakmai irányítása alá került. Jelenleg az eltelt évek kedvezőtlen tapasztalatai nyomán decentralizációs törekvések indultak el, zajlik a müködés átalakítása.

\footnotetext{
12 1997. évi CLIV. törvény az egészségügyről, 88. § (1)

13 1997. évi CLIV. törvény az egészségügyről, 89. § (1)

14 1997. évi CLIV. törvény az egészségügyről, 91 . § (1), (2)

15 1997. évi CLIV. törvény az egészségügyről, 92. § (1)

16 1997. évi CLIV. törvény az egészségügyről, 93. § - 106. §

17 1997. évi CLIV. törvény az egészségügyről, 42. § (5)
} 
A többletszolgáltatásban részesülő gyerekeket ellátó pedagógiai szakszolgálati intézmények rendszere átalakult, kétszintű intézményi struktúra jött létre. Megyénként (illetve a fővárosban) székhelyintézményként müködő pedagógiai szakszolgálati intézmények végzik a szakmai irányítást és koordinálást. A hierarchia második szintjén tankerületi illetőségű tagintézmények működnek (járási és fővárosi kerületi szinten), amelyek a jogszabályban meghatározott tevékenységek mellett szintén irányítási, képviseleti, szakmai feladatot látnak el ${ }^{18}$. A megyei és fővárosi pedagógiai szakszolgálati intézmény szakértői bizottságként eljáró országos tagintézménye az országos szakértői bizottság.

Az eddigi elkülönült intézményi keretek között müködő tevékenységek a pedagógiai szakszolgálat által ellátandó tevékenységek közé kerültek. A pedagógiai szakszolgálatok látják el a gyógypedagógiai tanácsadás, korai fejlesztés, oktatás és gondozás, a fejlesztő nevelés, a szakértői bizottsági tevékenység, a nevelési tanácsadás, a logopédiai ellátás, a konduktív pedagógiai ellátás, a gyógytestnevelés, az iskola- és óvodapszichológiai ellátás, a kiemelten tehetséges gyerekek gondozása, valamint a későbbi életkorokban a továbbtanulási, pályaválasztási tanácsadás feladatát ${ }^{19}$. Ebből kilenc tevékenység érinti a korai életszakaszt.

- A gyógypedagógiai tanácsadás, korai fejlesztés, oktatás és gondozás tartalmazza a komplex gyógypedagógiai fejlesztést, tanácsadást, a társas, a kommunikációs és nyelvi készségek fejlesztését, a mozgásfejlesztést és a pszichológiai segítségnyújtást ${ }^{20}$. Korai fejlesztést csak a megyei szakszolgálatok szakértői bizottságai javasolhatnak, az ellátást a pedagógiai szakszolgálat biztosítja ${ }^{21}$. A korai fejlesztés és gondozás feladatait a szakértői bizottság szakértői véleménye alapján, a gyermeket ellátó fejlesztő szakemberek által kidolgozott egyéni fejlesztési tervben foglaltak szerint kell végezni ${ }^{22}$. Ha a gyermek harmadik életévét betöltötte, akkor vehet részt korai fejlesztésben és gondozásban, ha a szakértői bizottság szakértő véleménye alapján nem kapcsolódhat be az óvodai nevelésbe ${ }^{23}$.

- A fejlesztő nevelés komplex gyógypedagógiai fejlesztés, melynek feladata a gyermek fejlesztő nevelés-oktatásra való felkészítése a szülö bevonásával, a szülő részére tanácsadás nyújtásával ${ }^{24}$. Ez a súlyosan, halmozottan fogyatékos, sajátos nevelési igényű gyermekeknek nyújtott szolgáltatás, akik attól az évtől kezdve, amelyben az ötödik életévüket betöltik, fejlesztő nevelésben vehetnek részt ${ }^{25}$

A szakértői bizottsági tevékenység keretében a pedagógiai szakszolgálat szakértői bizottsága a gyermek (a tanuló) komplex pszichológiai, pedagógiaigyógypedagógiai, továbbá szükség szerint (sajátos nevelési igény gyanúja esetén minden esetben szükséges) orvosi vizsgálat alapján szakértői véleményt készít. A vizsgálat célja lehet (a) az iskolába lépéshez szükséges fejlettség megállapítása, (b) a beilleszkedési, a tanulási, a magatartási nehézség megállapítása vagy kizárása, (c) a sajátos nevelési igény - a mozgásszervi, az érzékszervi (látási, hallási), az értelmi, a beszédfogyatékosság, több fogyatékosság együttes előfordulása esetén a halmozott fogyatékosság, az autizmus spektrum zavar vagy az egyéb pszichés fejlődési zavar: súlyos tanulási, figyelem- vagy magatartásszabályozási zavar ${ }^{26}$ - megállapítása vagy kizárása.

\footnotetext{
18 2013. (II. 26.) EMMI rendelet a pedagógiai szakszolgálati intézmények müködéséröl, 3. § (4)

19 2011. évi CXC. köznevelési törvény, 18. § (2)

20 15/2013 (II. 26.) EMMI rendelet a pedagógiai szakszolgálati intézmények működéséröl, 4. § (1)

21 15/2013 (II. 26.) EMMI rendelet a pedagógiai szakszolgálati intézmények működéséröl, 1. §

22 15/2013 (II. 26.) EMMI rendelet a pedagógiai szakszolgálati intézmények működéséről, 5. §

23 15/2013 (II. 26.) EMMI rendelet a pedagógiai szakszolgálati intézmények müködéséről, 4. § (4)

24 A 2011. évi CXC. törvény a nemzeti köznevelésről 18. § (2) bekezdés b) pontja szerint

25 15/2013. (II. 26.) EMMI rendelet a pedagógiai szakszolgálati intézmények müködéséröl 6. § (1)

26 2011. évi CXC. törvény a nemzeti köznevelésröl, 4. §
} 
- A nevelési tanácsadói tevékenység során a munkatársak segítséget nyújtanak a gyermek családi, és óvodai (valamint a későbbiekben az iskolai) neveléséhez. A szülővel feltáró beszélgetést végeznek, felmérik a gyermek adaptív viselkedését, szociális érettségét. A vizsgálat eredményeképpen tanácsadásban részesítik a szülőt, vagy a szakszolgálati ellátásba vétel szükségességét határozzák meg. A prevenciós tevékenység keretében a nevelési tanácsadás szakemberei együttmüködnek a védőnői és gyermekorvosi hálózattal, a gyermek korai fejlődési időszakában teljes körü családi mentálhigiénés intervenciót biztosíthatnak, valamint az óvodai nevelésben részesülö, negyedik életévüket betöltött gyermekek körében a tanulási és beilleszkedési nehézségek megelőzése céljából - a szülő előzetes hozzájárulásával - szürést végezhetnek ${ }^{27}$.

- A logopédiai ellátás feladata a beszédindítás, a hang-, beszéd- és nyelvfejlödési elmaradás, a beszédhibák és a nyelvi-kommunikációs zavarok javítása, a diszlexia, a diszortográfia, a diszgráfia, a diszkalkulia kialakulásának megelőzése a logopédiai terápiás foglalkozáson. A logopédiai ellátás igénybevétele néhány kivételtől eltekintve-önkéntes alapon történik. A logopédiai ellátás keretében el kell végezni az óvodai nevelésben részt vevő, ötödik életévüket betöltött gyermekek beszéd- és nyelvi fejlettségének alapvizsgálatát, szűrését, és ennek eredménye alapján szükség szerint a gyermek további pedagógiai, pszichológiai, orvosi vizsgálatának kezdeményezését ${ }^{28}$.

- A konduktív pedagógiai ellátás a központi idegrendszeri sérült gyerekek konduktív nevelése, fejlesztése és gondozása. A konduktív pedagógiai ellátás az óvodai neveléshez (iskolai neveléshez és oktatáshoz) kapcsolódóan vagy egyéni fejlesztő foglalkozás keretében nyújtható. A fejlesztő foglalkozás a szakértői bizottság szakértői véleményében meghatározottak szerint lehet egyéni vagy csoportos foglalkozás. A konduktív pedagógiai ellátás feladatainak megvalósításában a szülö közremüködhet. A konduktív pedagógiai ellátás a tanév rendjéhez igazodik és év közben is megkezdhetö 29 .

- A gyógytestnevelés feladata a gyermek (a tanuló) speciális egészségügyi célú testnevelési foglalkoztatása, ha szakorvosi (vagy iskolaorvosi) vizsgálat gyógytestnevelésre utalja. Ennek megszervezését és személyi feltételeinek biztosítását a pedagógiai szakszolgálat végzi a nevelési-oktatási intézményekben ${ }^{30}$.

- A pedagógiai szakszolgálati intézményben az óvodapszichológiai (és az iskolapszichológiai) ellátás feladata a nevelési-oktatási intézményekben dolgozó pszichológusok munkájának összefogása és segítése, amelyet az óvodapszichológus (és az iskolapszichológus) feladatok koordinátora lát el. A koordinátor feladatai közé tartozik többek között az óvodai (és az iskolai) preventív szürések tankerületi szintű koordinációja, a nevelési-oktatási intézményekből érkező pedagógusok számára egyéni tanácsadás és konzultáció biztosítása vagy a pedagógiai szakszolgálatnál bejelentkező, az óvodától (iskolától) független szolgáltatást igénylő szülők és gyermekek óvodai (iskolai) problémákkal összefüggő ellátása ${ }^{31}$.

- A kiemelten tehetséges gyermekek (tanulók) gondozása keretében a pedagógiai szakszolgálat feladata a korai tehetség-felismerés, tehetségazonosítás, amelynek során a tehetséggondozó koordinátor a tehetséges gyermek támogatásán túl a szülőknek tanácsadást, a pedagógusok részére konzultációt, a tehetségfejlesztő programok vezetőivel és az óvodapszichológussal (iskolapszichológussal) szakmai kapcsolattartást biztosít ${ }^{32}$.

\footnotetext{
27 15/2013 (II. 26.) EMMI rendelet a pedagógiai szakszolgálati intézmények működéséről, 24. §

28 15/2013 (II. 26.) EMMI rendelet a pedagógiai szakszolgálati intézmények működéséröl, 25. $§$

29 15/2013 (II. 26.) EMMI rendelet a pedagógiai szakszolgálati intézmények működéséről, 27. $§$

30 15/2013 (II. 26.) EMMI rendelet a pedagógiai szakszolgálati intézmények működéséről, 28. §

31 15/2013 (II. 26.) EMMI rendelet a pedagógiai szakszolgálati intézmények müködéséröl, 29. §

32 15/2013 (II. 26.) EMMI rendelet a pedagógiai szakszolgálati intézmények müködéséröl, 30 . §
} 
Az egységes gyógypedagógiai, konduktív pedagógiai módszertani intézmény (EGYMI) a többcélú intézmények közé tartozik, ahol a sajátos nevelési igényü gyermekek, tanulók többi gyermekkel (tanulóval) együtt történő nevelésének (oktatásának) támogatását végzik. Minden intézményben működnie kell kizárólag a sajátos nevelési igényű gyermekeket (tanulókat) ellátó óvodai (általános iskolai, fejlesztő nevelés-oktatást végző iskolai vagy középfokú iskolai) feladatot ellátó intézményegységnek, továbbá utazó gyógypedagógusi, utazó konduktori hálózatnak vagy - az országos és megyei szakértői bizottsági feladatok kivételével - pedagógiai szakszolgálati feladatokat ellátó intézményegységnek ${ }^{33}$. Az EGYMI feladata a többségi intézményekben a sajátos nevelési igényủ gyermekek integrációjának segítése. Ezt utazótanári hálózat megszervezésével és működtetésével látják el. Az utazó tanári feladat ellátás keretében a foglalkozásokon (tanórán) kívüli habilitációs/rehabilitációs foglalkozások kerülnek megtartásra. Az ellátást minden gyermek számára sérülésspecifikusan biztosítják.

A koragyermekkori intervenciós intézményrendszer elemei közé tartozik az óvoda is, hiszen az iskoláskor előtti gyerekek ellátásában (adott esetben speciális szolgáltatások nyújtásával) részt vesz. Az óvodai nevelés szakasza a gyermek hároméves korában kezdődik, és addig az időpontig tart, ameddig a gyermek a tankötelezettség teljesítését meg nem kezdi ${ }^{34}$. Ha a gyermek (a tanuló) beilleszkedési, magatartási (tanulási) nehézséggel küzd, fejlesztő foglalkoztatásra jogosult. A fejlesztő foglalkoztatás a nevelési tanácsadás, az óvodai nevelés (a későbbiekben az iskolai nevelés, oktatás) keretében valósítható meg. A sajátos nevelési igényű gyermekek óvodai nevelése az e célra létrehozott gyógypedagógiai nevelési intézményben, konduktív pedagógiai intézményben, óvodai csoportban, vagy a többi gyermekkel részben vagy egészben együtt, azonos óvodai csoportban történhet. A gyermek külön óvodai nevelését végző óvodai csoportot a sajátos nevelési igény típusának megfelelően hozzák létre. $A$ gyógypedagógiai nevelésben (és oktatásban) részt vevő intézményekben a gyermek egészségügyi és pedagógiai célú habilitációs és rehabilitációs ellátásban is részesül 35 .

\subsection{Szociális és gyermekvédelmi rendszer}

A szociális ágazatban a Szociális és Gyermekvédelmi Főigazgatósághoz került az állami irányítás. A főigazgatóság és területi kirendeltségei látják el a kormányhatározatban leírt szociális, gyermekjóléti és gyermekvédelmi intézmények fenntartói és módszertani feladatait. Ahhoz, hogy akár az egészségügyi alapellátás, akár a köznevelés területén dolgozó szakemberek megfelelő módon segíteni tudják az általuk ellátott gyerekeket és családjaikat, ismerniük kell a szociális alapszolgáltatásokat (pl. családsegítő szolgálat, falu- és tanyagondnoki szolgálat, támogató szolgálat), valamint a szociális ellátások, juttatások rendszerét. Így a pénzbeli ellátásokat (pl. emelt összegű családi pótlék, ápolási díj, rendszeres szociális segély) vagy a természetben nyújtható ellátásokat (pl. lakásfenntartási támogatás) ${ }^{36}$.

A társágazati szakemberek a szociális alapszolgáltatások mellett gyakran kerülnek kapcsolatba a gyermekvédelmi ellátás szereplőivel is ${ }^{37}$. A gyermekvédelmi védőháló alapvetően 3 fő alappilléren nyugszik: az alapellátás, a szakellátás és a hatósági

\footnotetext{
33 2011. évi CXC. köznevelési törvény, 20. § (9)

34 2011. évi CXC. törvény a nemzeti köznevelésről 5. § (1)

35 2011. évi CXC. törvény a nemzeti köznevelésröl 47. §

${ }^{36}$ Lásd 1993. évi III. törvény a szociális igazgatásról és szociális ellátásokról

37 Lásd továbbiakban 1997. évi XXXI. törvény a gyermekek védelméröl és a gyámügyi igazgatásról
} 
intézkedések intézményén. Itt is találunk pénzbeli és természetbeni ellátási formákat (pl. rendszeres gyermekvédelmi kedvezmény, óvodáztatási támogatás stb.) A gyermekvédelmi alapellátáshoz tartoznak a gyermekjóléti szolgáltatások (így maga a gyermekjóléti szolgálat), a gyermekek napközbeni ellátása (pl. bölcsődék, családi napközi, családi gyermekfelügyelet stb.) és a gyermekek átmeneti gondozása (pl. gyermekek átmeneti otthona, családok átmeneti otthona, helyettes szülö), valamint a Biztos Kezdet Gyerekházak.

A gyermekjóléti szolgáltatás akkor igyekszik minél hatásosabb támogatást nyújtani a családoknak, amikor veszélyben a harmonikus családi élet, de a gyermek kiemelését még nem indokolja a fennálló problémák mértéke. A gyermekek napközbeni ellátása keretében a családban élő gyermekek életkorának megfelelő nappali felügyeletét, gondozását, nevelését, foglalkoztatását és étkeztetését kell megszervezni azoknak az esetében, ahol a szülők, nevelők, gondozók valamilyen okból (pl. munkavégzésük, betegségük) miatt napközbeni ellátásukról nem tudnak gondoskodni ${ }^{38}$. A gyermekek átmeneti gondozása alapvetően olyan típusú segítségnyújtás, ami szülőknek segít életük rendezésében, ha egészségi állapotuk, életvezetési problémájuk, indokolt távollétük vagy más akadályoztatásuk miatt nem tudják megoldani a családban a gyermekük nevelését. Megszervezhető a gyermekek átmeneti otthonában, a családok átmeneti otthonában, vagy befogadó szülői szolgáltatáson, illetve a gyermekek átmeneti házi gondozásán keresztül. A gyermekek átmeneti otthona akkor nyújt segítséget, ha a gyermek megfelelő fejlődése veszélyeztetetté válik. A családok átmeneti otthona a komoly bajba került, de a család egységének megőrzéséért tenni hajlandó családoknak segít. Ezek olyan intézmények, ahova az anyák - elöfordul, hogy az apák is - a gyermekükkel, gyermekeikkel meghatározott időre beköltözhetnek, hogy legyen idejük körülményeik rendezésére (pl. munkavállalás, adósságrendezés, albérlet-keresés stb.). A befogadó szülöi szolgáltatás minden esetben a szolgáltatást nyújtó személy saját otthonában valósul meg, míg a gyermekek átmeneti házi gondoskodása esetén a gyermek saját otthonában maradhat, a segítő szakember a gyermek otthonában végzi a munkáját ${ }^{39}$.

A preventív szemlélet jegyében érdemes külön kiemelni az ún. Biztos Kezdet Gyerekházakat, amelyek jelenleg a Gyerekesély program keretén belül müködnek. Olyan alapellátó segítséget kínálnak elsősorban szociálisan hátrányos helyzetű családoknak, amely a hatékony prevenció érdekében 0-5 év közötti gyerekek és szüleik együttes jelenlétére épül. A bölcsődei, óvodai ellátás mellett ez az ellátási forma egy olyan alternatív segítséget jelent ezeknek a családoknak, amit a 0-5 éves korú gyerekek a szüleikkel együtt vehetnek igénybe. A Biztos Kezdet Gyerekházak dedikált célja többek között, hogy a szülöket hozzásegítsék az önálló(bb) szülői, családi életvezetési készségek elsajátításához. Ennek érdekében minden program a szülőkkel és gyerekekkel közösen történik, aminek köszönhetően a jelen lévő anyák, apák maguk is könnyebben fejlődhetnek a harmonikus családi élethez nélkülözhetetlen helyzetek kezelésében, pl. a gyermekkel történő játék, egészséges ételek készítése, személyes higiéné stb. területén.

A gyermekvédelmi szakellátáshoz soroljuk a családból kiemelt gyerekeknek biztosított otthont nyújtó ellátást (pl. nevelőszülő, gyermekotthon), az utógondozói ellátást és a területi gyermekvédelmi szakszolgáltatást. Az otthont nyújtó ellátás

\footnotetext{
38 1997. évi XXXI. törvény a gyermekek védelméröl és a gyámügyi igazgatásról 41.§

39 1997. évi XXXI. törvény a gyermekek védelméről és a gyámügyi igazgatásról, 44/A.§.
} 
keretében biztosítani kell az ideiglenes hatállyal elhelyezett, a nevelésbe vett gyermek számára a családi környezetébe történő visszahelyezését elökészítő, családi kapcsolatainak ápolását segítő családgondozást, vagy ha ez nem lehetséges, az örökbefogadásának elősegítését. Az utógondozói ellátás a fiatal felnőttek számára nyújtott szolgáltatás. Érdemes még ismerni a területi gyermekvédelmi szakszolgáltatás intézményét, amely javaslatot tesz a gyermek ideiglenes gondozási helyére és a gyermek sorsának rendeződéséig a számára otthont nyújtó ellátást biztosító gondozási helyére. A gyámhivatalok képviselik a törvény erejét hatóságként. Ök hozzák meg a döntéseket a szükséges gyermekvédelmi intézkedésekről - védelembe vétel, gyermek kiemelése, kapcsolattartás, a gyermek hazagondozása stb.

\section{Utak és kapcsolódások}

Az egyes ágazatokon belüli továbbküldési, jelzési utak viszonylag jól leírtak a jogszabály alapján, de a különböző ágazati irányítás alá tartozó intézményes szereplőket a felismeréstől az ellátásba kerülésig nem köti össze szabályozott gyermekút. A koragyermekkori intervenciós ellátásokat tekintve az egészségügy rendszere és a szociális, gyermekvédelmi rendszer érintőlegesen kapcsolódik össze, elsősorban a gyermekjóléti szolgálat intézményén keresztül, ugyanakkor a köznevelés rendszerébe az egészségügyi ellátórendszerből nem vezet út. A szociális, gyermekvédelmi terület és a köznevelés között is inkább a jelzőrendszerben való együttmüködés, illetve a pedagógiai szakszolgálati tevékenység kapcsán azonosíthatóak érintkezési pontok.

A gyermek útja több szakaszra tagolható, a prekoncepcionális szakasztól a várandósság és a perinatális időszakon keresztül a hazakerülés utáni szakaszig, egészen a gyermek iskolába lépéséig. Minden szakaszban megtalálhatóak azok a kulcsintézmények, illetve szereplők, amelyek/akik az ellátásban részt vesznek, feladataik jogszabály által meghatározottak, és a továbbküldési, jelzési utak is azonosíthatóak.

\subsection{Prekoncepcionális szakasz}

A prekoncepcionális időszakban, amikor a szülők még csak tervezik a gyermeket, elsősorban az egészségügyi ellátórendszerben kapnak ehhez támogatást. A Családvédelmi Szolgálat védőnője tanácsadást végez, illetve az oktatási intézményeken kívül a családtervezéssel kapcsolatos ismeretek terjesztését szervezi ${ }^{40}$. A területi védőnő szintén a családtervezéssel kapcsolatos tanácsadást végzi ${ }^{41}$, az iskolai védőnő pedig az egészségtan oktatásában vesz részt, ahol elsősorban az családtervezés, fogamzásgátlás, szülői szerep, csecsemőgondozás témájára fókuszál ${ }^{42}$. A háziorvos feladata ebben a szakaszban az egészségnevelés és az egészségügyi felvilágosítás ${ }^{43}$. A szülész-nőgyógyász szakorvos a család- és nővédelmi gondozás keretében a gyermekvállalás optimális biológiai és pszichés körülményeinek elősegítését végzi, a fogamzás előtti gondozás és genetikai tanácsadás, valamint a termékenységi ciklus alatti gondozás eszközeivel ${ }^{44}$. A gyermeket tervező pár akár a területi védőnőhöz, akár a háziorvoshoz vagy a Családvédelmi Szolgálathoz fordul, a szülész-nőgyógy-

\footnotetext{
40 1992. évi LXXIX. évi törvény a magzati élet védelméről 2. § (2).

41 49/2004. (V. 21.) ESzCsM rendelet a területi védőnői ellátásról 3. §

42 26/1997. (IX.3.) NM rendelet az iskola-egészségügyi ellátásról 3. számú melléklet

43 4/2000. (II.25.) EüM rendelet a háziorvosi, házi gyermekorvosi és fogorvosi tevékenységről 4. § (2)

44 1997. évi CLIV. törvény az egészségügyröl 41. §
} 
A koragyermekkori intervenció rendszere - utak és kapcsolódások

ász szakorvoshoz irányítják őket. Ennek a szakasznak a jelenlegi szabályozás szerint nincs hangsúlyos szerepe, miközben a prekoncepcionális időszakra sokkal nagyobb figyelmet kellene fordítani kiemelkedő prevenciós jelentősége okán.

\subsection{Várandósság szakasza}

A várandósság szakaszában a magzat egészséges fejlődésének ellenőrzése, a veszélyeztetettség és a szövődmények megelőzése, illetve megfelelő időben történő felismerése, valamint a szülésre, szoptatásra és csecsemőgondozásra való felkészítés a család- és nővédelmi gondozás keretében valósul meg ${ }^{45}$. A várandósgondozás a háziorvos, a szülész-nőgyógyász szakorvos, a várandós választása esetén a szülésznő és a védőnő együttmüködésében zajlik ${ }^{46}$. A védőnő a gondozás során tudomására jutott mindazon körülményröl tájékoztatja a várandósgondozást végző szülész-nőgyógyászt/szülésznőt, amelyek befolyásolhatják a magzat egészséges fejlődését ${ }^{47}$.

A szociális, gyermekvédelmi intézmények közül a gyermekjóléti szolgálat érintett leginkább ebben a szakaszban. Feladata a válsághelyzetben lévő várandós anya támogatása, segítése, tanácsokkal való ellátása, valamint számára a családok átmeneti otthonában igénybe vehető ellátáshoz való hozzájutás szervezése ${ }^{48}$. Amennyiben a várandós anya nem vállalja születendő gyermeke felnevelését, tájékoztatják őt a nyílt és a titkos örökbefogadás lehetőségéről ${ }^{49}$. Veszélyeztetettség esetén az egészségügyi szolgáltatást nyújtóknak, a védőnői szolgálatnak, a háziorvosnak, a várandós nő kezelőorvosának jelzési kötelezettsége van a gyermekjóléti szolgálat felé ${ }^{50}$. A gyermekjóléti szolgálat és az illetékes védőnő haladéktalanul tájékoztatják egymást, ha a várandós anya válsághelyzetben van ${ }^{51}$. A gyakorlatban azonban ezek az oda-visszajelzési utak nem müködnek megfelelően. Mindkét fél hiányolja a másik jelzésre adott válaszát, illetve az érdemi intézkedésröl való tájékoztatást.

\subsection{Perinatális szakasz}

A perinatális szakaszban a gyermek a megszületése után optimális esetben az újszülött osztályra kerül, ahol elvégzik az alapvizsgálatokat és a kiegészítő vizsgálatokat (laboratóriumi, képalkotó, konzíliumok, anyagcsere vizsgálat). A koraszülöttek, illetve az érett, de problémás újszülöttek protokoll szerint a neonatális/perinatális centrumokba kerülnek, ahol szintén lezajlanak a megfelelő szűrővizsgálatok.

Amennyiben a szülő lemond a gyermekéről, a kórház értesíti a gyámhatóságot a gyermek örökbefogadhatóságáról ${ }^{52}$. Veszélyeztetettség esetén a területi védőnő, házi gyermekorvos felé küld jelzést az intézmény, mint az egészségügyi szolgáltatást nyújtók közül a kiemelt jelző szereppel rendelkező ellátók felé (akik pedig a gyermekjóléti

\footnotetext{
45 1997. évi CLIV. törvény az egészségügyről 86. § (1) (2)

46 26/2014. (IV.8.) EMMI rendelet a várandósgondozásról 6. §

47 26/2014. (IV.8.) EMMI rendelet a várandósgondozásról 9. § (2)

48 1997. évi XXXI. törvény a gyermekek védelméröl és a gyámügyi igazgatásról, 39. § (2)

49 15/1998. (IV. 30.) NM rendelet a személyes gondoskodást nyújtó gyermekjóléti, gyermekvédelmi intézmények, valamint személyek szakmai feladatairól és müködésük feltételeiről, 11. § (2)

50 1997. évi XXXI. törvény a gyermekek védelméröl és a gyámügyi igazgatásról, 17. § (1) (2)

51 15/1998. (IV. 30.) NM rendelet a személyes gondoskodást nyújtó gyermekjóléti, gyermekvédelmi intézmények, valamint személyek szakmai feladatairól és müködésük feltételeiröl, 11. § (3)

52 149/ 1997 (IX.10.) Korm. rendelet a gyámhatóságokról valamint a gyermekvédelmi és gyámügyi eljárásról, 64/A $\S$
} 
szolgálatnak jeleznek) ${ }^{53}$. A gyermek megszületéséről, illetve a gyógyintézetből való távozásról a kórházi védőnő írásban értesíti a területi védőnőt valamint a választott házi gyermekorvos vagy háziorvost ${ }^{54}$. A további gondozás során nagyon fontos a két szakterület részéröl egymás kölcsönös tájékoztatása (gyermek fejlődése, felmerült problémák stb.).

\subsection{Hazakerülés után}

A gyermek megszületése után, a kórházból való hazaérkezést követően az újszülöttet meglátogatja a védőnő, majd a szokásjog alapján a házi gyermekorvosa, háziorvosa. A védőnő és a házi gyermekorvos, háziorvos együttmüködve végzi a gyermekek ellátását/gondozását, az előírt szürővizsgálatokat, tanácsadást. Amennyiben a védőnő a szürés során eltérést tapasztal, tájékoztatja a gyermek házi gyermekorvosát, háziorvosát, egyben hozzáküldi a szülőt is. Ha valamilyen probléma merül fel a gyermeknél, járóbeteg-szakellátóhoz vagy a betegsége/állapota szerint illetékes fekvőbeteg intézménybe/osztályra irányítják. Az egészségügy rendszerében a fogadó intézményben történő terápiás ellátás mellett egészségügyi habilitációt, rehabilitációt végző magánellátók is részt vesznek az ellátásban, házi gyermekorvos, háziorvos és szakellátó szakorvos is irányít oda gyerekeket ${ }^{55}$.

Mivel az egészségügyi és a pedagógiai ellátást végző intézményeket nem köti össze jogszabály, probléma észlelése esetén az egészségügyi ellátó csak javasolhatja a pedagógiai szakszolgálat felkeresését, de nem utalhatja ellátásba a gyermeket. Amennyiben a probléma a gyermek 0-3 éves kora között merül fel, a sajátos nevelési igény megállapítása, illetve a korai fejlesztés megkezdésére való javaslattétel a megyei szakértői bizottság feladata. Ellátási helyszínként a gyermek lakóhelyéhez legközelebb lévő tankerületi pedagógiai szakszolgálati tagintézményt jelölik ki. Amennyiben az ellátás ott nem megoldható, a gyermek fejlesztésére otthoni ellátás keretében vagy a pedagógiai szakszolgálati intézmény fenntartójával infrastruktúra-használatra vonatkozó szerződést kötött intézményben kerül sor ${ }^{56}$

Az utóbbi néhány évben az ágazaton belüli és az ágazatok közötti profiltisztítás jegyében a feladatellátást tekintve több intézményben is változások történtek. Korábban bölcsődék, gyermekotthonok, fogyatékos személyek otthonai és nappali intézményei is végezhették a korai fejlesztés feladatát. Jelenleg ezekben az intézményekben a tevékenységet - amennyiben ehhez a feltételek adottak - a pedagógiai szakszolgálat szakemberei biztosítják ${ }^{57}$. Az egységes gyógypedagógiai, konduktív pedagógiai módszertani intézményekben - ahol szintén folyhatott korábban korai fejlesztés -, most a szakemberek szakszolgálati keretek között végezhetik a tevékenységet. Alapítványi intézmények, amennyiben szakszolgálati feladatot ellátnak, és szerződést kötnek a fenntartóval illetve a minisztériummal, szintén elláthatják a feladatot. Fontos fejlemény, hogy a pedagógiai szakszolgálatok szakértői bizottsága a tizennyolc hónapnál fiatalabb gyermekek szakértői véleményét a gyermek külön vizsgálata nélkül, a gyermekneurológiai szakorvos által felállított diagnosztikai vélemény és terápiás ja-

\footnotetext{
53 1997. évi XXXI. törvény a gyermekek védelméröl és a gyámügyi igazgatásról, 17. § (1) (2)

54 49/2004. (V.21.) ESZCSM rendelet a területi védőnői ellátásról 3/A. §

55 2003. évi LXXXIV. törvény az egészségügyi tevékenység végzésének egyes kérdéseiről, 3. §, 7. §

56 15/2013 (II. 26.) EMMI rendelet a pedagógiai szakszolgálati intézmények müködéséröl, 1. §

57 15/2013. (II. 26.) EMMI rendelet a pedagógiai szakszolgálati intézmények müködéséröl, 4.§. (3)
} 
A koragyermekkori intervenció rendszere - utak és kapcsolódások

vaslat alapján is elkészítheti ${ }^{58}$. Így minél hamarabb ellátásba kerülhet a gyermek, nem kell hosszú hónapokat várni a szakértői bizottság vizsgálatára ahhoz, hogy a szakemberek megkezdhessék a terápiás, fejlesztő foglalkozásokat.

A 3 évnél idősebb gyerekek esetében a tankerületi szakértői bizottság feladata a teljes körü pszichológiai, pedagógiai-gyógypedagógiai vizsgálat. Ha a tankerületi szakértői bizottság megítélése szerint a gyermeknél a sajátos nevelési igény valószínűsíthető, továbbküldi a gyermeket a megyei szakértői bizottság felé, annak dokumentációs anyagával együtt ${ }^{59}$. A mozgásszervi fogyatékosság, az érzékszervi (a látási, a hallási) fogyatékosság, valamint a beszédfogyatékosság megállapítását vagy kizárását országos feladatellátási kötelezettséggel az országos szakértői bizottság végzi azzal, hogy a beszédfogyatékosság megállapítása vagy kizárása a megyei szakértői bizottság feladatai körében is ellátható. Szakértői vizsgálat néhány kivételtől eltekintve a szülő kérelmére, illetve egyetértésével indul. Ha a gyermek óvodai nevelésben részesül, az óvoda köteles közremüködni a vizsgálat iránti kérelem elkészítésében ${ }^{60}$.

A gyermekvédelmi törvény alapján, veszélyeztetettség esetén az egészségügyi szolgáltatást nyújtóknak, a védőnői szolgálatnak, a házi gyermekorvosnak/háziorvosnak, a személyes gondoskodást nyújtó intézményeknek (pl. bölcsőde, családi napközi) és a köznevelési intézményeknek (óvoda, pedagógiai szakszolgálatok) veszélyeztetettség esetén jelzési kötelezettségük van a gyermekjóléti szolgálat felé. A gyermek bántalmazása, súlyos elhanyagolása vagy más, súlyos veszélyeztető ok fennállása, továbbá a gyermek súlyos veszélyeztető magatartása esetén kötelesek hatósági eljárást kezdeményezni61.

\section{Az ellátásba kerülést akadályozó rendszerszintű és strukturális problémák}

Korábbi kutatási eredmények szerint Magyarországon a koragyermekkori intervenciós ellátásra szoruló gyerekek több mint egyharmada nem kapja meg a számára szükséges ellátást, szolgáltatást (Kereki és Lannert, 2009). Ennek többféle oka van, rendszerszintű problémák és strukturális egyenlőtlenségek egyaránt állnak a háttérben. A koragyermekkori intervenció több ágazatot is érint, ám a területet komplexitása miatt nehéz ágazati megközelítéssel koherensen lefedni. Egyelőre hiányzik a koragyermekkori intervenció egységes rendszerként való kezelése és ennek a szabályozásban való tükröződése, a jogszabályok összehangolása. A változó szabályozási környezet mellett a finanszírozási háttér bizonytalansága is gondot okoz a múködésben.

Az együttmüködések döntéshozói és helyi ellátói szinten is többnyire kialakulatlanok. A szakemberek nem ismerik egymás kompetenciáit, illetve ezek a kompetenciák nem tisztázottak. Az intézményrendszer átalakulása, a szociális és a köznevelés területén zajló centralizációs törekvések bizonytalanságot okoznak a szolgáltatói hálózatban. A szülök és a szakemberek egyaránt információhiánnyal küzdenek. Mindhárom ágazatban jellemző a minőségi standardok hiánya, a szakmai kontroll gyengesége, de a szisztematikus mérés és visszacsatolás sem müködik megfelelően. A rendszerben nagyon sok adat keletkezik, de az adatgyűjtések nem összehangoltak. Hiányoznak a korszerü, standardizált szürési módszerek, vizsgáló eljárások (Kereki, 2013).

58 Lásd 15/2013 (II. 26.) EMMI) a pedagógiai szakszolgálati intézmények működéséről, 4. §. (2)

59 15/2013 (II. 26.) EMMI rendelet a pedagógiai szakszolgálati intézmények működéséről, 11. §. (1) (2)

60 15/2013 (II. 26.) EMMI rendelet a pedagógiai szakszolgálati intézmények működéséről, 13.§.

61 1997. évi XXXI. törvény a gyermekek védelméröl és a gyámügyi igazgatásról, 17.§ (2). 
A koragyermekkori intervenciós rendszerben az egyik legnagyobb problémát a szakember-ellátottság hiányosságai okozzák. Az egészségügyi ellátás területén kritikusan alacsony a feladatokhoz mért csecsemő- és gyermek szakorvosok száma, ez az alapellátás és a szakellátás területén is megmutatkozik ${ }^{62}$. A pedagógiai szakszolgálatoknál a szakértői bizottsági tevékenységet végző szakemberek körében az esetszámra jutó szakemberlétszám kevés, folyamatos túlterheltséget okoz, ami meghosszabbítja a vizsgálatra való várakozás idejét (Kereki, 2011). A koragyermekkori intervencióban résztvevő szakembereknek a korai ellátással kapcsolatban megszerzett tudása egyenetlen, képzésbeli hiányosságok azonosíthatók. Az egyes diagnózisokhoz illesztett terápiás, fejlesztő eljárások megválasztását sokszor nem csak a szakember kapacitás szűkössége határolja be, de a rendelkezésre álló szakemberek képzettsége, szakértelme is, amely nem feltétlenül igazodik a speciális szükségletekhez (Kere$k i, 2011)$.

Az ellátásokhoz való hozzáférést a szolgáltatások biztosításának területi egyenlötlenségei is erőteljesen befolyásolják, amelyek szinte minden típusú szolgáltatást érintenek. Az egészségügyi ellátás mutatói alapján Észak-Magyarország és ÉszakAlföld egészségügyi ellátása a legkedvezőtlenebb. A csecsemőhalandósági mutató Észak-Magyarországon hosszabb ideje kiugróan magas értéket mutat. Nemcsak a házi gyermekorvosokra jutó gyermeklétszám tartozik a legmagasabbak közé, de a szakorvosok is itt a legleterheltebbek. A védőnői támogatás szintén a két északi régióban a legkevésbé biztosított. Országosan hiányzik a jól szervezett utógondozói hálózat, a neuroterápiás, ill. gyermekrehabilitációs szolgáltatások terén nem biztosított a regionális ellátás, szűkös a kapacitás. A gyermekjóléti és gyermekvédelmi ellátások, valamint a családsegítő szolgáltatások hozzáférési, hatékonysági problémákkal küzdenek. A gyermekek napközbeni ellátása országosan megoldatlan, a helyzet ÉszakMagyarországon a legkritikusabb (Kereki, 2011).

A koragyermekkori intervenciós ellátásban részesülő gyerekek több mint $50 \%$ át Budapesten látják el, jellemző, hogy a nagyvárosokban szerveződnek színvonalas ellátást nyújtó intézmények, de a kisebb településeken, különösen a falvakban lakók számára a speciális szolgáltatások elérhetetlenek (Kereki és Lannert, 2009). Az ellátáshoz való hozzáférés akadályozottsága különösen a hátrányos helyzetű régiókban, elsősorban Észak-Magyarországon jellemző, ahol éppen azok a családok nem kapnak a rendszertől támogató segítséget, akik maguk sem elég tudatosak a probléma felismerésében és kezelésében. A szakorvosi beutalásra vagy a korai terápiás, fejlesztő ellátásba való eljutást az utaztatási nehézségek és az anyagi források szűkössége erősen befolyásolja. Gyakorlatilag a családok egy részének anyagi helyzetéből fakadóan elérhetetlenek bizonyos szolgáltatási formák (Kereki, 2010). A szociális, gyermekvédelmi jelzőrendszer (családsegítő, gyermekjóléti szolgálat) sokat tud segíteni abban, hogy az arra rászoruló gyerekek minél hamarabb ellátásba jussanak. Ahol a három különböző ágazat intézményei közötti kapcsolati háló elég kiterjedt és intenzív, gyorsabb az információáramlás, korábban bejutnak a gyerekek a pedagógiai jellegü intézményekbe (Kereki, 2010).

62 Semmelweis terv az egészségügy megmentésére (2011): Újraélesztett egészségügy. Gyógyuló Magyarország. Nemzeti Erőforrás Minisztérium, Egészségügyért Felelős Államtitkárság. 2011. június 27. 


\section{Összefoglalás}

A koragyermekkori intervenciós rendszerben azonosított problémák megoldására az utóbbi időben több fejlesztési projekt is kísérletet tett.

Az egészségügy égisze alatt zajló TÁMOP 6.1.4. Koragyermekkor (0-7 év) projekt az egészségügyi alapellátás munkájának támogatására, korszerű tudással való felvértezésére irányul. A gyermekek fejlődését befolyásoló rizikó- és védőtényezők beazonosítása, az eltérő fejlődést mutató gyermekek mielőbbi kiszürése, a gyermekek fejlődésének nyomon követése kiemelt figyelmet kap a célok között. Új, szülői megfigyelésen alapuló kérdőív került kifejlesztésre, amely a hozzá kapcsolódó tájékoztató anyagokkal azt szolgálja, hogy a szülők kompetensebbek legyenek saját gyermekük fejlődésének nyomonkövetésében. Ezzel párhuzamosan korszerü módszertani kiadványok, számos tananyag, képzések segítik a védőnők, házi gyermekorvosok/háziorvosok munkájának hatékonyabb végzését ${ }^{63}$.

A jelenlegi köznevelési területhez kapcsolódik a TÁMOP-3.4.2.B, a „Sajátos nevelési igényű gyerekek integrációja (Szakszolgálatok fejlesztése)" kiemelt projekt, amelynek keretében a pedagógiai szakszolgálatok tevékenységeinek támogatására protokollok készültek, köztük a koragyermekkori intervencióra és a gyógypedagógiai tanácsadás, korai fejlesztés, oktatás és gondozás tevékenységre kifejlesztett protokoll (Kereki és Szvatkó, 2015). A TÁMOP 3.1.1. „XXI. századi közoktatás (fejlesztés, koordináció)" nevű szintén kiemelt projektben pedig kidolgozásra és kipróbálásra került a koragyermekkori intervenció rendszerében használható kliensút modell (Kereki, 2015).

A szociális ágazatban a TÁMOP 5.2.6. - „A korai életszakaszban feltárt fejlődési rendellenességek, lemaradások kezeléséhez való hozzáférések javítása" projekt a korai ellátásban résztvevő szociális, gyermekvédelmi, gyermekjóléti intézményekben dolgozó szakemberek tudását bővíti családtámogató törekvések keretében adaptált képzési anyagokkal.

Bár mindezek a törekvések nagy haladást jelentenek a leírt problémák megoldásában, a jövőben számtalan területen kell további lépéseket tenni azért, hogy egy hatékonyan müködő, egységes szemléletű koragyermekkori intervenciós rendszer müködhessen Magyarországon. Többek között szükség lenne a szabályozás és a finanszírozás egységes szemléletủ átalakítására, összehangolására, a különböző ágazati irányítás alá tartozó intézményeket összekötő, rendszerszinten megvalósuló szabályozott kliensút bevezetésére. Ehhez pedig elengedhetetlen az egységes, integrált elektronikus dokumentáció és az adatszolgáltatás kiépítése, az informatikai felszereltség bővítése, az adatbázisok összekapcsolása. A szükségletekhez jobban illeszkedő szolgáltatásnyújtás érdekében a speciális terápiás, fejlesztő szolgáltatások választékának bővítése, a többoldalú tudással rendelkező szakemberek számának növelése, illetve kompetenciáinak fejlesztése szükséges. A szakemberek tudásbővítéséhez, egységes szemléletük formálásához, a családokkal való partneri együttmüködés kialakításához közös képzési programok megvalósítása indokolt. A szülők felkészítése, edukálása, kompetenciáinak bővítése, valamint megfelelő információval való ellátása nagyobb hangsúlyt kell, hogy kapjon, mint ahogy a családok szolgáltatásokhoz való egyenlő esélyü hozzáférésének biztosítása is sarkalatos pontja kell, hogy legyen a jövőbeni elképzeléseknek.

\footnotetext{
63 Lásd Gyermek-alapellátási Információs Portál. www.gyermekalapellatas.hu.
} 


\section{Irodalom}

A Gyermek jogairól szóló ENSZ Egyezmény (1989): http://www.szmm.gov.hu/download. php?ctag=download\&doclD=14922 (Letöltés dátuma: 2015. 03.05.)

Almqvist, L. (2009): Early Childhood Intervention. Project update. Country Report - Sweden. European Agency for Development in Special Needs Education. http://www.europeanagency.org/agency-projects/early-childhood-intervention (Letöltve: 2015.03.03.)

Andrews, E. (2009): Early Childhood Intervention. Project update. Country Report - UK (England). European Agency for Development in Special Needs Education.

URL: http://www.european-agency.org/agency-projects/early-childhood-intervention (letöltve: 2015.03.03.)

Carneiro, P. és Heckman, J. J. (2003): Human Capital Policy. In: Heckman J. és Krueger A. (eds.): Inequality in America: What Role for Human Capital Policy? MIT Press. 77-240.

Carpenter, B. és Russel, P. (2005): Early Intervention int he United Kingdom. In: Guralnick, M. J. (ed.): The Developmental Systems Approach to Early Intervention. Brookes, Baltimore, 455-480.

Czeizel Barbara (2009): A koragyermekkori intervenció múltja, jelene és remélt jövője. Gyógypedagógiai Szemle, 2-3. 153-159.

Doyle, O., Harmon, C.P., Heckman, J.J. és Tremblayd, T.R. (2009): Investing in Early Human Development: Timing and Economic Efficiency. Econ Hum Biol. 7. March; 7(1): 1-6.

EADSNE - European Agency for Development in Special Needs Education (2005). Early Childhood Intervention: Analysis of Situations in Europe - Key Aspects and Recommendations. European Agency for Development in Special Needs Education, Odense. http://www.european-agency.org/ (Letöltés dátuma: 2015. 03.06.)

EADSNE - European Agency for Development in Special Needs Education (2010): Early childhood intervention. Progress and Developments 2005-2010. European Agency for Development in Special Needs Education, Odense,

URL: https://www.european-agency.org/sites/default/files/early-childhood-interventionprogress-and-developments_ECl-report-EN.pdf (letöltve: 2015. 03.06.)

ENSZ Nyilatkozat a gyermekek jogairól (1958):

http://unicef.hu/c/document_library/get_file?p_I_id=23940\&noSuchEntryRedirect=viewFull ContentURLString\&fileEntryld=24686 (letöltve: 2015.03 .05 .)

Early Support (2012): Key working: improving outcomes for all.

URL: http://www.councilfordisabledchildren.org.uk/resources/our-partners-resources/ key-working-improving-outcomes-for evidence-provision-systems-and-structures (letöltve: 2015.03.10.)

Euronews (2006): Az Ügynökség „Korai fejlesztés: az európai helyzet elemzése” címü projektje. URL: http://www.european-agency.org/news/euronews/euronews-15/euronews15_hu.pdf (letöltve: 2015.03. 06.)

Guitez, P. (2010): Early Childhood Intervention in Spain: Standard Needs ad Changes. In: Pretis, M. (ed.): Early Childhood Intervention Across Europe. Towards Standards, Shared Resources And National Challenges. Maya, Ankara, 83-98.

Heckman, J. J. (2008a): The case for Investing in Disadvantaged Young Children. In: First Focus (ed.): Big Ideas for Children: Investing in Our Nation's Future. First Focus, 49-58

Heckman, J. J. (2008b). Schools, skills and synapses. Economic Inquiry 46 (3), 289-324.

Heinämäki, L. (2009) Early Childhood Intervention Project update. Country Report - Finland. European Agency for Development in Special Needs Education.

URL: http://www.european-agency.org/agency-projects/early-childhood-intervention (letöltve: 2015.03.04.)

Helgevold, L. (2009): Early Childhood Intervention. Project update. Country report - Norway. European Agency for Development in Special Needs Education.

URL: http://www.european-agency.org/agency-projects/early-childhood-intervention (letöltve: 2015.03.04.)

ICSSZEM - Ifjúsági, Családügyi, Szociális és Esélyegyenlőségi Minisztérium, Fogyatékosügyi Főosztály (2005): Értékelemzési zárójelentés a korai fejlesztés koncepciójának kialakitásáról. Kézirat. MicroVA Bt. 
A koragyermekkori intervenció rendszere - utak és kapcsolódások

Kereki Judit és Lannert Judit (2009, írta és szerk.): A korai intervenciós intézményrendszer hazai müködése. Kutatási zárójelentés. Kézirat. TÁRKI-TUDOK ZRT - FSZK, Budapest.. URL: http://www.fszk.hu/opi/szolgaltatas/koraiintervencio/FINAL_0302_MODOSITOTT_ Zarotanulmany_KORINT.pdf

Kereki Judit (2010): A kora gyermekkori intervenció intézményrendszerének anomáliái és jó gyakorlata. Gyógypedagógiai Szemle, 38. (1.) 32-45.

Kereki Judit (2001, írta és szerk.): Regionális helyzetértékelés a kora gyermekkori intézményrendszer hálózatos fejlesztésének megalapozásához. Kutatási zárójelentés. Educatio Társadalmi Szolgáltató Nonprofit Kft, Budapest.

URL: http://www.educatio.hu/pub_bin/download/tamop_311/4piller/regionalis_ helyzetertekeles_kezirat.pdf

Kereki Judit (2013): A koragyermekkori intervenciós rendszer müködésének legfontosabb problématerületei és fejlesztési lehetőségei. Gyógypedagógiai Szemle, 61. (1.) 23-38.

Kereki Judit és mtsai (2014): Gyermekút - jogszabályok, gyakorlat, lehetséges modell. TÁMOP-6.1.4 Koragyermekkori program, Országos Tisztiföorvosi Hivata, Budapest.

Kereki Judit (2014): Majd kinövi (?). A koragyermekkori intervenciós rendszer és a korai fejlesztés. Hallgatói Kézikönyv. TÁMOP-6.1.4 Koragyermekkori program, Gyógyszerészeti és Egészségügyi Minőség- és Szervezetfejlesztési Intézet, Budapest.

Kereki Judit (2015, szerk.): Kliensút Kalauz. Educatio Társadalmi Szolgáltató Nonprofit Kft., Budapest.

Kereki Judit és Szvatkó Anna (2015): A koragyermekkori intervencióra valamint a gyógypedagógiai tanácsadás, korai fejlesztés, oktatás és gondozás pedagógiai szakszolgálati tevékenységi területre kifejlesztett protokoll. Educatio Társadalmi Szolgáltató Nonprofit Kft, Budapest.

Libro Blanco (2000): Libro blanco de la atención temprana. Documentos 55/2000. Madrid, Ministerio de Trabajo y Asuntos Socales y Real Patronato de Prevención y de Atención a Personas con Minusvalía.

URL: http://www.altxa.com/wp-content/uploads/Libro-Blanco-de-la-Atencion-Temprana.pdf (letöltve: 2014.11.27.)

Libro Blanco (2005): Libro blanco de la atención temprana. Documentos 55/2005. Madrid, Ministerio de Trabajo y Asuntos Socales y Real Patronato de Prevención y de Atención a Personas con Minusvalía.

URL: http://www.fcsd.org/libro-blanco-de-la-atenci\%C3\%B3n-precoz_69992 (letöltve: 2014.11.27.)

Luttropp, A. M., Norling, M. B. és Balton, M. (2007): Intervention practice for preschool children in need of special support: A comparative analysis between South Africa and Sweden. URL: http://www.up.ac.za/dspace/bitstream/2263/6274/1/Luttropp_ Intervention\%282007\%29.pdf (letöltve: 2015.03. 06.)

Peterander, F. (2004): Early Childhood Intervention in Bavaria (Germany). European Agency for Development in Special Needs Education.

URL: www. european-agency.org (letöltve: 2015.03.10.)

Peterander, F. (2009): Early Childhood Intervention Project update. Country Report - Germany (Bavaria). European Agency for Development in Special Needs Education.

URL: www. european-agency.org (letöltve: 2015.03.10.)

Ponte Mittelbrunn, M. J. (2004): Early Childhood Intervention in Spain. European Agency for Development in Special Needs Education.

URL: www.european-agency.org (letöltve: 2015.03.03.)

Robertson, C. és Messenger, W. (2010): Early Childhood Intervention in the UK: Family, Needs, Standards and Challenges. In: Pretis, M. (ed.): Early Childhood Intervention Across Europe. Towards Standards, Shared Resources and National Challenges. Maya, Ankara, 112-126.

Semmelweis terv az egészségügy megmentésére. (2011): Újraélesztett egészségügy. Gyógyuló Magyarország. Nemzeti Erőforrás Minisztérium, Egészségügyért Felelős Államtitkárság. 2011. június 27. 
Shonkoff, J. P. és Phillips, D. A. (2000): From neurons to neighbourhood. The Science of Early Childhood development. National Academy Press, Washington.

Svendsen, I. (2009): Early Childhood Intervention. Project update. Country Report - Danmark. European Agency for Development in Special Needs Education.

URL: http://www.european-agency.org/agency-projects/early-childhood-intervention (letöltve: 2015. 03. 03.)

United Nations Organization (1993): The Standard Rules ont he Equalization of Opportunities for Persons with Disabilities. UN, New York.

URL: http://www.un.org/disabilities/default.asp?id=26 (letöltve: 2015. 03.05.)

Veerman, E. R. (2009): Early Childhood Intervention. Project update. Country report - Spain. European Agency for Development in Special Needs Education.

URL: http://www.european-agency.org/agency-projects/early-childhood-intervention (letöltve: 2015. 03. 03.)

\section{Jogszabályok}

1993. évi III. törvény a szociális igazgatásról és szociális ellátásokról

1997. évi XXXI. törvény a gyermekek védelméröl és a gyámügyi igazgatásról

1997. évi CLIV. törvény az egészségügyröl

2011. évi CXC. törvény a nemzeti köznevelésröl

1998. évi XXVI. törvény a fogyatékos személyek jogairól és esélyegyenlöségük biztosításáról 2003. évi XXV. törvény az egyenlő bánásmódról és az esélyegyenlöség elömozdításáról

1991. évi LXIV. törvény a Gyermek jogairól szóló, New Yorkban, 1989. november 20-án kelt Egyezmény kihirdetéséröl

15/1998. (IV. 30.) NM rendelet a személyes gondoskodást nyújtó gyermekjóléti, gyermekvédelmi intézmények, valamint személyek szakmai feladatairól és müködésük feltételeiröl

1/2000. (I. 7.) SzCsM rendelet a személyes gondoskodást nyújtó szociális intézmények szakmai feladatairól és müködésük feltételeiröl

15/2013. (II.26.) EMMI rendelet a pedagógiai szakszolgálati intézmények müködéséröl

1992. évi LXXIX. évi törvény a magzati élet védelméröl

26/1997. (IX.3.) NM rendelet az iskola-egészségügyi ellátásról

217/1997. (XII. 1.) Korm. rend.az 1997. évi LXXXIII. törvény a kötelező egészségbiztosítás ellátásairól a végrehajtásáról

4/2000. (II.25.) EüM rendelet a háziorvosi, házi gyermekorvosi és fogorvosi tevékenységröl

60/2003. (X. 20.) ESzCsM rendelet az egészségügyi szolgáltatások nyújtásához szükséges szakmai minimumfeltételekröl

49/2004. (V. 21.) ESzCsM rendelet a területi védőnői ellátásról

29/2012. (III. 7.) Korm. rendelet a közszolgálati tisztviselők képesítési elöírásairól

26/2014. (IV.8.) EMMI rendelet a várandósgondozásról 